\title{
Investigation on Characterization and Pyrolysis of Some Coals from Mongolia
}

\author{
Purevsuren Barnasan ${ }^{1, *}$, Batkhishig Damdin ${ }^{1}$, Batbileg Sanjaa ${ }^{1}$, Battsetseg \\ Munkhtaivan $^{1}$, Ankhtuya Ariunbold ${ }^{1}$, Jargalmaa Soninkhuu ${ }^{1}$, Avid Budeebazar ${ }^{1}$, \\ Ariunaa Aleksandr ${ }^{1}$, Peter Kuznetsov ${ }^{2}$
}

\author{
${ }^{1}$ Institute of Chemistry and Chemical Technology, MAS, Ulaanbaatar-51, Mongolia \\ ${ }^{2}$ Institute of Chemistry and Chemical Technology, SB RAS \\ *Corresponding author. Email: bpurevsuren.icct@gmail.com
}

\begin{abstract}
This study reports the technical characteristics, the organic elemental composition of coal, and the inorganic elemental composition of coal ashes from four selected coals including Tavan tolgoi, Nariin sukhait, Baganuur and Shivee-Ovoo deposits in Mongolia. The thermal stability analyses of the organic mass in coal samples were also conducted with thermogravimetric analysis and discussed with the detailed mechanisms of the thermal decomposition of the coal organic mass. Furthermore, the coal samples were processed by pyrolysis at different heating temperatures and determined the yields of pyrolysis products such as hard residue, condensed liquid (tar and pyrolysis water), and uncondensed gas products. The coal ashes from the selected coals were also studied in detail and report that the ashes of high-rank coals of Tavan tolgoi and Nariin sukhait deposits have acidic character and ashes of low-rank coals of Baganuur and Shivee-Ovoo deposits have alkaline character. In addition, the coals samples from Tavan tolgoi, Nariin sukhait, Shivee-Ovoo, and Baganuur deposits were processed by pyrolysis at different heating temperatures and determined with the yields of pyrolysis products such as hard residue, condensed liquid (tar and pyrolysis water), and uncondensed gas products. The yields of hard residue from high-rank coals of Tavan tolgoi and Nariin sukhait were higher than that of low-rank coals of Baganuur and Shivee-Ovoo coal. The dewatered tar products of pyrolysis were investigated for chemical composition analysis.
\end{abstract}

Keywords: High-rank coal, Low-rank coal, Bituminous coal, Thermogravimetric analysis, Thermal stability indices, Pyrolysis tar, Pyrolysis hard residue

\section{INTRODUCTION}

Mongolia is among the 10 coal-rich countries in the world with 175 billion tonnes of geologically estimated coal resources including high-quality bituminous coking coals, subbituminous coals, and lignite brown coals. More than $70 \%$ of coal resources belong to the brown coals [1]. The Tavan tolgoi and Nariin sukhait deposits are the biggest and most important for the export of Mongolia bituminous coking coals and Baganuur and Shivee-Ovoo deposits are also the biggest and most important for the internal energy system in Mongolia brown coals. The Tavan tolgoi and Nariin sukhait deposits locate in the South Gobi Region and Baganuur and Shivee-Ovoo deposits locate just in the Central Economic Region of Mongolia.

In general, coal undergoes a series of physical and chemical changes during pyrolysis. Various pyrolysis conditions (i.e. coal type, pyrolysis temperature, atmosphere, heating rate, and catalyst factors) 
significantly affect these physical and chemical changes [2-5]. On the other hand, pyrolysis is an efficient treatment method of organic material at elevated temperatures in the absence of oxygen. It involves the simultaneous change of chemical composition and physical phase during thermochemical decomposition of organic material by heat and is irreversible [6-8]. As a result of pyrolysis, a solid (hard residue), condensed liquid (tar and pyrolysis water), and gas (uncondensed) products can be obtained. From these products, the solid product can be used as coke, semicoke, smokeless fuel, and adsorbent material based on its properties of a porous and higher caloric value. Tar is petroleumlike product and can be used as complex raw material for the production of chemical substances, gasoline, diesel, oils, bitumen, and so on. The gas product can be used as gas fuel after cleaning nitrogen and sulphur-containing pollutants in it $[6,7]$. Generally, before the pyrolysis experiments of coal necessary to carry out thermogravimetric analysis to investigate the mechanism of thermal decomposition coal organic mass and to determine the thermal stability characteristics such as thermostability indices $\left(\mathrm{T}_{5} \%\right.$ and $\mathrm{T}_{25} \%$ ) and to evaluate how are easy for pyrolysis $[9,10]$. During the last decade, we are working on pyrolysis of some organic raw materials including different rank coals $[11,12]$, oil shale [13-15], wood waste [16-18], animal bone [19, 20], cedar shell [21], polypropylene waste [22], milk casein [23-25] and characterization of obtained hard residue, tar and gas product after pyrolysis.

The conversion of coal into oil and gas is a major issue in the country, which will affect national safety and economically sustainable development. Therefore, more detailed investigations by using modern instrumental analysis such as FTIR and thermogravimetric analysis and different pyrolytic experimental methods are very important for the future development of coal processing industries in Mongolia. For this reason, the coals of Tavan tolgoi, Nariin sukhait, Baganuur, and Shivee-Ovoo deposits in Mongolia have been chosen the detailed investigation on thermal processing including pyrolysis and characterization of obtained solid (hard residue) and liquid products after pyrolysis.

\section{EXPERIMENTAL}

\subsection{Sample Preparation}

Four coals were crushed into small pieces 3-6 mm in size and the analytical sample was prepared by powdering the coal into small particles size $<0.2 \mathrm{~mm}$ in a steel mill. Analytical sample preparation (MNS 27192001), proximate and ultimate analysis of coal were performed according to Mongolian National Standards MNS 656-79 (moisture content), MNS 652-79 (ash yield), MNS 654-79 (volatile matter yield).

The elemental composition of coal was determined by microanalytical instrument 5E C2000, model CNH-analyser. The FTIR spectrum of coal was obtained on a Nicolet 20-PC FTIR spectrometer with CsI optics and DTGS detector. The $\mathrm{KBr}$ disc contained a $0.5 \%$ finely ground coal sample. All the spectra were measured in the frequency range of 4000 to $400 \mathrm{~cm}^{-1}$, and 32 scans were taken for every sample.

\subsection{Thermogravimetric Analysis}

Thermogravimetric analysis of coal was carried out in TG/DTA7200, (Hitachi, Japan). Conditions of analysis were as follows: Sample weight $-5-10 \mathrm{mg}$. Heating temperature range $-20-1150^{\circ} \mathrm{C}$, Heating rate $-20^{\circ} \mathrm{C} / \mathrm{min}$, Carrier gas-argon, Crucible made by Pt$\mathrm{Rh}$.

\subsection{Pyrolysis Analysis}

Small-scale pyrolysis experiments of coal samples were performed in a laboratory quartz retort (tube) which could process $1 \mathrm{~g}$ of coal sample. The retort was placed in a horizontal electric tube furnace. A chrome-alumel thermocouple was immersed in the tube furnace to measure the actual heating temperature. Pyrolysis experiments have been carried out at different temperatures $200-700^{\circ} \mathrm{C}$ with a constant heating rate of $20^{\circ} \mathrm{C} / \mathrm{min}$. First of all, the quartz retort with coal sample was heated, for example, to $600^{\circ} \mathrm{C}$ with a heating rate of $20^{\circ} \mathrm{C} / \mathrm{min}$, and kept at $700^{\circ} \mathrm{C}$ for $80 \mathrm{~min}$. The retort was connected with a thermostable glass tube heated also in a tube furnace at $80^{\circ} \mathrm{C}$ for collecting tar. This tube was also connected with an air-cooled glass vessel for collecting pyrolysed water. The glass vessel for pyrolysed water was connected with a thin glass tube for non-condensable gases. The yields of pyrolysed products, including solid residue (biochar), tar (condensed liquid product), and pyrolysed water were determined by weighing, and the yield of gases was determined based on their differences.

For the collection of more quantities of pyrolysis hard residue and liquid tar products have used a bigger scale pyrolysis apparatus. The vertical cylindrical retort is made of stainless steel in which 1 $\mathrm{kg}$ of coal sample can be pyrolized. The retort was placed in an electric furnace (model SNOL) with a maximum temperature of $950^{\circ} \mathrm{C}$. A chrome-alumel 
thermocouple was immersed in the coal bed to measure the actual heating temperature with temperature control (potentiometer). The retort was connected with an air-cooled iron tube and the watercooled laboratory glass condenser and a collection vessel for the condensate of liquid product (pitch and pyrolysis water). The non-condensable gases after water-cooled condenser were left the system through a thin glass tube. The experiments were carried out to a $500^{\circ} \mathrm{C}$ temperature and the heating rate was $20^{\circ} \mathrm{C} / \mathrm{min}$. The yields of products including solid residue (coal char), tar, and pyrolysis water were determined by weighing, and the yield of gases by difference.

\subsection{Method for Separation of Tar and Pyrolysis Water}

The liquid product of coal pyrolysis consists of tar and pyrolysed water. They form unmixed two layers and can be separated easily by separating in a glass funnel. The upper layer is tar (viscous liquid) with black-brown color and an unpleasant smell.

Table 1. The main technical characteristics and ultimate analysis of coal samples

\begin{tabular}{|c|c|c|c|c|c|c|c|c|}
\hline \multirow{2}{*}{ Coal deposits } & $\begin{array}{l}\text { Moisture, } \\
\%\end{array}$ & $\begin{array}{l}\text { Ash, } \\
\%\end{array}$ & $\begin{array}{l}\text { Volatile } \\
\text { matter, \% }\end{array}$ & $\begin{array}{l}\text { Caloric value, } \\
\text { ксal/kg }\end{array}$ & $\begin{array}{l}\text { Carbon, } \\
\%\end{array}$ & $\begin{array}{l}\text { Hydrogen, } \\
\%\end{array}$ & $\begin{array}{l}\text { Nitrogen, Oxygen } \\
\text { and others, } \%\end{array}$ & $\begin{array}{l}\text { Sulfur, } \\
\%\end{array}$ \\
\hline & $\mathrm{W}^{\mathrm{a}}$ & $\mathrm{A}^{\mathrm{d}}$ & $\mathrm{V}^{\text {daf }}$ & $\mathrm{Q}_{\mathrm{s}}^{\mathrm{daf}}$ & $\mathrm{C}^{\text {daf }}$ & $\mathrm{H}^{\mathrm{daf}}$ & $(\mathrm{N}+\mathrm{O})^{\mathrm{daf}}$ & $\mathrm{S}^{\mathrm{a}}$ \\
\hline Tavan tolgoi IV am & 14.7 & 0.8 & 29.9 & 7524.0 & 84.0 & 5.4 & 10.2 & 1.0 \\
\hline Nariin sukhait & 1.0 & 15.8 & 36.9 & 7685.0 & 84.9 & 4.4 & 10.7 & 1.6 \\
\hline Shivee-Ovoo & 13.4 & 21.2 & 41.0 & 6501.0 & 71.3 & 4.9 & 22.6 & 1.1 \\
\hline Baganuur & 9.4 & 13.3 & 47.0 & 6848.0 & 70.5 & 5.7 & 23.3 & 0.5 \\
\hline
\end{tabular}

The bottom layer is pyrolysed water (non-viscous liquid) with an unpleasant smell and yellowish in color. The final cleaning of tar was done by mixing with thermally treated $\mathrm{CaCl}_{2}$ and through separation using filtering or centrifuging. The products, yellowish pyrolysed water with a gravity of 0.9227 $\mathrm{g} / \mathrm{cm}^{3}$ and a solid residue with $7.2 \%$ were obtained after evaporation at room temperature.

\section{RESULTS AND DISCUSSION}

We have determined the technical characteristics, ultimate analysis of coal, and inorganic elemental composition of coal ash in four selected coal samples including Tavan tolgoi, Nariin sukhait, Baganuur, and Shivee-Ovoo deposits in Mongolia are show in Table 1. The results of proximate and ultimate analysis of coal samples show that the caloric value and carbon content are higher for the coal samples of Tavan tolgoi and Nariin sukhait deposits than that of Shivee-Ovoo and Baganuur coal deposits. Besides, the contents of volatile matter and oxygen contents of coal samples of Tavan tolgoi and Nariin sukhait deposits are lower than that of Shivee-Ovoo and Baganuur coal deposits. The content of sufur is lower in all coal samples, which is good from an environmental point of view.

We further analzed the coal samples by FTIR analysis for the characterization of coal organic mass Figure 1.

The IR-spectrum (Figure 1) of initial coal samples show that there are absorbtion bands with low intensities characterizing high molecular polymerized material.

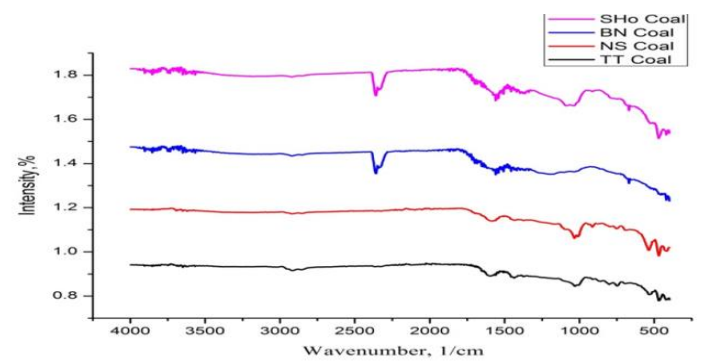

Figure 1. The FTIR spectrum of Tavan tolgoi (TT), Nariin sukhait (NS), Baganuur (BN) and ShiveeOvoo (ShO) coal

Figure 1 shows that there are lower intensity absorption bands of $-\mathrm{CH}_{3},-\mathrm{CH}_{2}, \quad-\mathrm{CH}$ groups connected with aliphatic and aromatic radicals at $2800-2900 \mathrm{~cm}^{-1}$, for $>\mathrm{CO}$, $-\mathrm{COOH}$, groups connected with mostly aromatic radicals at $1600 \mathrm{~cm}^{-1}$, for aromatic -CH groups at 1438 and $700-900 \mathrm{~cm}^{-1}$. In the IR spectrum (Figure 1, NS) of Nariin sukhait coal, there are several week absorption bands for - $\mathrm{CH}$ aromatic group at $500-750 \mathrm{~cm}^{-1}$ and for aliphatic $-\mathrm{CH} ;-\mathrm{CH}_{2}$ and $-\mathrm{CH}_{3}$ groups with middle intensity at $1249 \mathrm{~cm}^{-1}$ and a sharp bands with higher intensity at $2854-2923 \mathrm{~cm}^{-1}$. Also, a strong absorption bands for $>\mathrm{C}=\mathrm{O}$ groups at $1600 \mathrm{~cm}^{-1}$, week bands for -Ogroups at $1400 \mathrm{~cm}^{-1}$ and for C-O- groups at 1000$1100 \mathrm{~cm}^{-1}$. Therefore, the coal organic mass of Nariin sukhait coal consists mainly of the aliphatic, aromatic, and aromatic-aliphatic structures with the above-mentioned groups inside. 
IR spectrum of Baganuur coal can be recognized following absorption frequency regions:700-900 $\mathrm{cm}^{-1}$ for $\mathrm{C}_{\mathrm{ar}} \mathrm{H}$; $1000-1300 \mathrm{~cm}^{-1}$ for vibration of bonds in various oxygen-containing groups; $1350-1470 \mathrm{~cm}^{-1}$ for vibrations of $-\mathrm{CH},-\mathrm{CH}_{2}$, and $-\mathrm{CH}_{3}$ groups; 1500 $630 \mathrm{~cm}^{-1}$ for skeletal vibrations of aromatic rings, $>\mathrm{C}=\mathrm{O}$ bonds in ketones, aldehydes and quinines. In the IR spectrum (Figure 1, ShO) of Shivee-Ovoo coal, there are several weak absorption bands for the $\mathrm{CH}$ aromatic group at $500-700 \mathrm{~cm}^{-1}$, and for aliphatic $-\mathrm{CH}-\mathrm{CH}_{2}$ and $-\mathrm{CH}_{3}$ groups with middle intensity at
$1250 \mathrm{~cm}^{-1}$. And, a strong absorption band for $>\mathrm{C}=\mathrm{O}$ groups at $1600 \mathrm{~cm}^{-1}$, weak band for -O- groups at $1400 \mathrm{~cm}^{-1}$ and for C-O- groups at $1000-1200 \mathrm{~cm}^{-1}$. Therefore, the coal organic mass of Shivee-Ovoo coal consists mainly of aliphatic, aromatic, and aromaticaliphatic structures. For investigation of the mineral matter of the four coals have obtained pure ash of each coal after completely burning the analytical coal sample at $950^{\circ} \mathrm{C}$ and tested it by FTIR analysis (Figure 2) and determined the mineral composition by using Roentgen fluorescence analysis (Table 2).

Table 2. The chemical composition of coals ashes (wt \%)

\begin{tabular}{|l|c|c|c|c|c|c|c|c|c|c|c|c|c|}
\hline \multicolumn{1}{|c|}{ Oxides } & $\mathbf{M g O}$ & $\mathbf{A l}_{2} \mathbf{O}_{3}$ & $\mathbf{S i O}_{2}$ & $\mathbf{S O}_{3}$ & $\mathbf{K}_{2} \mathbf{O}$ & $\mathbf{C a O}$ & $\mathbf{T i O}_{2}$ & $\mathbf{M n}_{2} \mathbf{O}_{3}$ & $\mathbf{F e}_{2} \mathbf{O}_{3}$ & $\mathbf{C u O}$ & $\mathbf{P b O}_{2}$ & $\mathbf{P}_{2} \mathbf{O}_{5}$ & $\mathrm{Ratio}^{\prime}$ \\
\hline TT & - & 15.7 & 77.6 & 1.9 & 0.5 & 1.9 & 0.9 & - & 0.7 & 0.1 & - & 0.6 & 0.03 \\
\hline NS & 2.5 & 17.1 & 22.8 & 7.3 & 3.0 & 14.8 & 2.7 & 0.6 & 27.5 & 0.1 & 0.9 & 0.4 & 0.4 \\
\hline SHO & 4.3 & 7.2 & 27.7 & 19.0 & 1.1 & 28.9 & 1.2 & 1.6 & 8.4 & - & - & - & 1.2 \\
\hline BN & 2.6 & 6.2 & 24.2 & 7.2 & 0.9 & 40.4 & 1.2 & 0.4 & 17.4 & 0.1 & 0.03 & - & 0.4 \\
\hline Elements & $\mathrm{Mg}$ & $\mathrm{Al}$ & $\mathrm{Si}$ & $\mathrm{S}$ & $\mathrm{K}$ & $\mathrm{Ca}$ & $\mathrm{Ti}$ & $\mathrm{Mn}$ & $\mathrm{Fe}$ & $\mathrm{Cu}$ & $\mathrm{Pb}$ & $\mathrm{P}$ & \\
\hline TT & - & 8.3 & 36.4 & 0.8 & 0.43 & 1.4 & 0.6 & - & 0.5 & - & - & - & \\
\hline NS & 1.5 & 9.0 & 10.6 & 2.9 & 2.5 & 10.6 & 1.6 & 0.4 & 19.3 & 0.1 & - & - & \\
\hline SHO & 1.5 & 9.0 & 10.6 & 2.9 & 2.5 & 10.6 & 1.6 & - & 19.3 & 0.1 & - & - & \\
\hline BN & 1.6 & 0.3 & 11.3 & 2.9 & 0.8 & 28.9 & 0.7 & 0.2 & 12.2 & 0.1 & - & 0.1 & \\
\hline
\end{tabular}

Ratio of oxides $-\left(\mathrm{Fe}_{2} \mathrm{O}_{3}+\mathrm{CaO}+\mathrm{MgO}+\mathrm{Na}_{2} \mathrm{O}+\mathrm{K}_{2} \mathrm{O}\right) /\left(\mathrm{SiO}_{2}+\mathrm{AI}_{2} \mathrm{O}_{3}+\mathrm{TiO}_{2}\right)$

Acidic $(\mathrm{Ac})<1<$ Alcaline $(\mathrm{Al})$

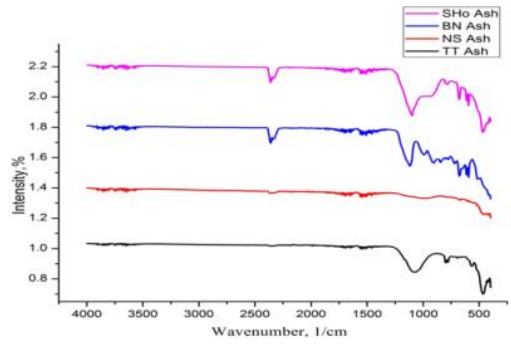

Figure 2. The FTIR spectrum of coal ashes of Tavan tolgoi (TT), Nariin sukhait (NS), Baganuur (BN) and Shivee-Ovoo (ShO) coal

The FTIR spectrum of four coal ashes of Tavan tolgoi (TT), Nariin sukhait (NS-only here is with middle intensity), Baganuur (BN) and Shivee-Ovoo (ShO) deposits in Figure 2 show that the most intensive and the biggest peak at $1150 \mathrm{~cm}^{-1}$ belongs for the Si-O- and $\mathrm{Ca}-\mathrm{O}$ - groups in $\mathrm{SiO}_{2}$ and $\mathrm{CaO}$ which have highest contents than other groups. Besides, there was another peak with middle intensity at $1100 \mathrm{~cm}^{-1}$ for -O-Al-group in $\mathrm{Al}_{2} \mathrm{O}_{3}$, and other peaks with lower intensities for -O-Fe-; -O-Mg- groups in $\mathrm{Fe}_{2} \mathrm{O}_{3}$ and $\mathrm{MgO}$ in the coal ash. In the case of Nariin sukhait (NS) coal ash, the most intensive and biggest peak at $1350 \mathrm{~cm}^{-1}$ belongs to the $-\mathrm{O}-\mathrm{Fe}$ group in $\mathrm{Fe}_{2} \mathrm{O}_{3}$.

Table 2 show that the coal ash of Tavan tolgoi (TT) deposit has the highest content of elements Si and $\mathrm{Al}$ and their oxides $\mathrm{SiO}_{2}$ and $\mathrm{Al}_{2} \mathrm{O}_{3}$, in the case of Baganuur (BN) and Shivee-Ovoo (SHO) coal ashes have the highest content of $\mathrm{Ca}$ and $\mathrm{Si}$ and their oxides $\mathrm{CaO}$ and $\mathrm{SiO}_{2}$. The contents of $\mathrm{Fe}$ and $\mathrm{Si}$ and their oxides $\mathrm{Fe}_{2} \mathrm{O}_{3}$ and $\mathrm{SiO}_{2}$ have the highest contents in the ash of Nariin sukhait (NS) coal, which is different than that of Tavan tolgoi coal ash. The contents of $\mathrm{Al}, \mathrm{Fe}, \mathrm{S}$, and $\mathrm{Mg}$ and their oxides $\mathrm{Al}_{2} \mathrm{O}_{3}$, $\mathrm{Fe}_{2} \mathrm{O}_{3}, \mathrm{SO}_{3}$, and $\mathrm{MgO}$ have middle contents in the coal ashes of Baganuur and Shivee-Ovoo deposits. Besides, the middle contents have $\mathrm{Al}, \mathrm{CaO}, \mathrm{S}, \mathrm{Mg}$ and $\mathrm{Ti}$ and their oxides in the Nariin sukhait coal ash and only $\mathrm{S}$ and $\mathrm{Ca}$ and their oxides in the coal ash of the Tavan tolgoi deposit. All other elements and their oxides determined in the four coal ashes have the lowest contents.

Table 3. The content of radioactive elements in coals and coal ashes

\begin{tabular}{|l|l|l|l|l|l|l|l|}
\hline \multirow{2}{*}{ Coal deposit } & \multicolumn{2}{|l|}{ The activity of isotopes, Bk/Kg } & \multicolumn{2}{l|}{ The content of radioactive elements } & \multirow{2}{*}{$\begin{array}{l}\text { Radium equivalent } \\
\text {, Bk/kg }\end{array}$} \\
\cline { 2 - 7 } & $\mathbf{R a - 2 2 6}$ & $\mathbf{T h}-\mathbf{2 3 2}$ & $\mathbf{K}-\mathbf{4 0}$ & $\mathbf{U}, \mathbf{g} /$ ton & Th, g/ton & $\mathbf{K}, \mathbf{\%}$ & 1.5 \\
\hline Tavan tolgoi IV coal & 13.4 & 6.0 & 460.2 & 1.1 & 1.5 & 60.4 \\
\hline Tavan tolgoi IV coal ash & 8.0 & 75.2 & 1203.0 & 6.4 & 18.4 & 4.0 & 278.9 \\
\hline Nariin sukhait coal & 8.0 & 1.3 & 29.4 & 0.7 & 0.3 & 0.1 & 5.5 \\
\hline Nariin sukhait coal ash & 67.0 & 26.0 & 130.0 & 5.5 & 6.3 & 0.4 & 110.2 \\
\hline
\end{tabular}




\begin{tabular}{|l|l|l|l|l|l|l|l|}
\hline Baganuur coal & 85.1 & 14.8 & 66.6 & 13.5 & 3.6 & 0.2 & 148.7 \\
\hline Baganuur coal ash & 2025.0 & 67.0 & 350.0 & 163.9 & 16.5 & 1.1 & 580.0 \\
\hline Shivee-Ovoo coal & 19.8 & 8.5 & 621.2 & 1.6 & 2.1 & 2.1 & 83.7 \\
\hline Shivee-Ovoo coal ash & 106.1 & 59.3 & 1177.0 & 8.7 & 14.5 & 3.9 & 283.1 \\
\hline
\end{tabular}

To determine the character (acidic or alkaline) of each coal ash was calculated the ratio between the following sum oxides:

$\left(\mathrm{Fe}_{2} \mathrm{O}_{3}+\mathrm{CaO}+\mathrm{MgO}+\mathrm{Na}_{2} \mathrm{O}+\mathrm{K}_{2} \mathrm{O} / \mathrm{SiO}_{2}+\mathrm{Al}_{2} \mathrm{O}_{3}+\mathrm{TiO}_{2}\right.$.

If this ratio is less than 1 , that coal ash has an acidic (Ac.) characteristic and it is more than 1 the coal ash has an alkaline (Al.) character Table 2.

The contents of radioactive elements in the analytical coal samples and their ashes were determined by gamma spectrometric analysis and the results are given in Table 3.

The contents of radioactive elements in the analytical coal samples of four deposits in Table 3 are lower, but their contents in their ashes increased (enriched) significantly for example the content of $U$, Th, and Ra 20 increased many times in comparison with initial coal samples.

The thermogravimetric analysis is the most useful method for the investigation of thermal decomposition and thermal stability of natural organic resources including coals. Therefore, the analytical coal samples of selected four coal samples were the object of thermogravimetric analysis and obtained TG curves Figure 3, DTA curves Figure 4, and DTG curves Figure 5.

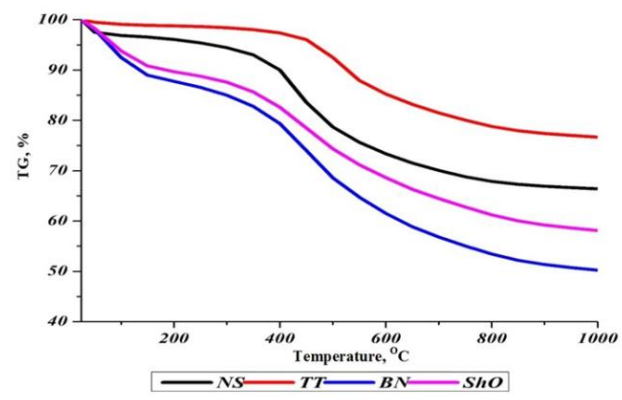

Figure 3. TG curves of Tavan tolgoi (TT), Nariin sukhait (NS), Baganuur (BN) and Shivee-Ovoo (ShO) coal

The heating of four coal samples at temperatures in the range of $25-1020^{\circ} \mathrm{C}$ in argon atmosphere, with a heating rate of $40^{\circ} \mathrm{C} / \mathrm{min}$ shows that the thermal decomposition of coals ended with about $20.0 \%$ weight loss and $80.0 \%$ hard residue at $1000^{\circ} \mathrm{C}$ for Tavan tolgoi coal, with about $32.0 \%$ weight loss and $68.0 \%$ hard residue at $1000^{\circ} \mathrm{C}$ for Nariin sukhait coal, with about $38.0 \%$ weight loss and $62.0 \%$ hard residue at $1000^{\circ} \mathrm{C}$ for Shivee-Ovoo coal and with about $48.0 \%$ weight loss and $52.0 \%$ hard residue at $1000^{\circ} \mathrm{C}$ for Baganuur coal, Figure 3. These results show that the high-rank coals of Tavan tolgoi and Nariin sukhait coals are more thermostable with lower weight loss than that of lower-rank coals of ShiveeOvoo and Baganuur coals with lower thermal stability. For this reason, three different thermal stability have been determined from each coal sample from the TG curves in Figure 3, Table 4.

Table 4. The thermal stability $\left(\mathrm{T}_{5} \%, \mathrm{~T}_{15} \%\right.$, and $\mathrm{T}_{25}$ $\%$ ) of four coal samples

\begin{tabular}{|l|c|c|c|}
\hline \multirow{2}{*}{ Coal deposits } & \multicolumn{3}{|c|}{ Thermalstabilty indices, ${ }^{\circ} \mathbf{C}$} \\
\cline { 2 - 4 } & $\mathbf{T}_{\mathbf{5}} \boldsymbol{\%}$ & $\mathbf{T}_{\mathbf{1 5}} \boldsymbol{\%}$ & $\mathbf{T}_{\mathbf{2 5}} \mathbf{\%}$ \\
\hline Baganuur & 55.3 & 159.6 & 411.2 \\
\hline Shivee-Ovoo & 78.8 & 347.8 & 434.1 \\
\hline Nariin sukhait & 425.3 & 498.6 & 620.0 \\
\hline Tavan tolgoi & 440.7 & 529.9 & 813.7 \\
\hline
\end{tabular}

In the thermal stability results, $\mathrm{T}_{5} \%$ indicates the beginning of thermal decomposition of the coal organic mass, whereas $\mathrm{T}_{15} \%$ indicates the middle period of thermal decomposition and $\mathrm{T}_{25} \%$ indicates the ending of thermal decomposition of coal sample. In addition, the thermal stability results show that the high-rank coals of Tavan tolgoi and Nariin sukhait have much higher thermal stability indices than that of lower rank coals of Shivee-Ovoo and Baganuur coals.

Table 5. The determined from the Figure 3 temperature intervals, ${ }^{\circ} \mathrm{C}$ of four coal samples

\begin{tabular}{|l|l|l|l|l|}
\hline \multirow{2}{*}{ Coal deposits } & \multicolumn{4}{|l|}{ The determined temperature intervals, ${ }^{\circ} \mathbf{C}$} \\
\cline { 2 - 5 } & I & II & III & IV \\
\hline Baganuur & $25-180$ & $180-380$ & $380-800$ & $800-1000$ \\
\hline Shivee-Ovoo & $25-180$ & $180-380$ & $380-800$ & $800-1000$ \\
\hline Nariinsukhait & $25-50$ & $50-390$ & $390-800$ & $800-1000$ \\
\hline Tavan tolgoi & $25-450$ & $450-800$ & $800-1000$ & - \\
\hline
\end{tabular}

As show in Table 5, the steps are different for high rank and low rank coals. These steps are similar for low rank coals of Baganuur and Shivee-Ovoo coals, and however, for Nariin sukhait coal I and II, the steps are much different than that of low rank coals. For the Tavan tolgoi coal, it has even only three steps. Usually, in I step, the weight loss is due to the release of some absorbed gas and moisture from the coal sample. In II step, intensive thermal decomposition of the organic matter of the coal samples start forming liquid (tar and pyrolysis water) 
and gas products. In III step, the weight loss strongly decreases, which is an indication for ending thermal decomposition and starting carbonization of the coal sample. In IV step, the weight loss lowly increases, which is related to the release of gas, e.g. $\mathrm{CO}_{2}, \mathrm{H}_{2}$, $\mathrm{CO}$ from the mineral matter of coal sample.

The first minimum peak of DTA at $105^{\circ} \mathrm{C}$ for Baganuur and Shivee-Ovoo coal shows the endothermic reaction process related to the releasing of the adsorbed gas and moisture from the coal sample.

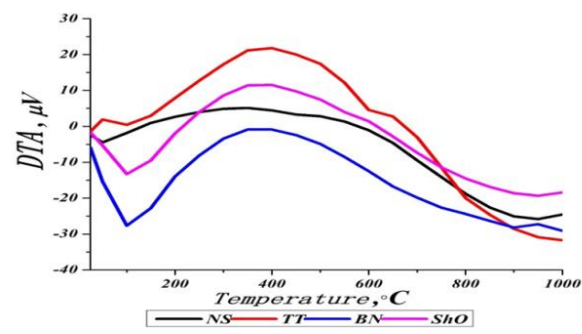

Figure 4. DTA curves of Tavan tolgoi (TT), Nariin sukhait (NS), Baganuur (BN) and Shivee-Ovoo (ShO) coal

A big exothermic reaction peak at $400^{\circ} \mathrm{C}$ related to the intensive thermal destruction of the coal organic mass from the sample. Also, the DTA curves of highrank coals of Tavan tolgoi and Shivee-Ovoo coals are much different than that of low-rank coals of Baganuur and Shivee-Ovoo coals. For example, the DTA curve of Nariin sukhait coal has a very little endothermic minimum.
The DTG curves of four coal samples indicate the first exothermic maximum as the sign of releasing of the moisture and adsorbed gas, and the second big exothermic peak as related to the thermal destruction reactions of coal organic mass with the maximum rate Figure 5.

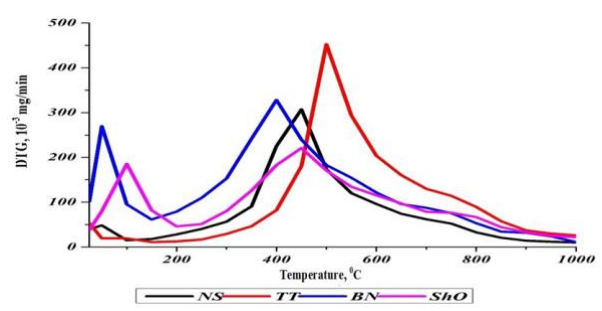

Figure 5. DTG curves of Tavan tolgoi (TT), Nariin sukhait (NS), Baganuur (BN) and Shivee-Ovoo (ShO) coal

The DTG curves differ with different temperature maximum points of exothermic peaks depending on the nature of coal organic mass of each coal samples. Pyrolysis is one method of the used thermal processing of coals to produce a solid (hard residue or semicoke and coke), condensed liquid (tar), and uncondensed gas product. For this reason, the four coal samples were pyrolyzed in a standard quartz retort at different heating temperatures $\left(200^{\circ} \mathrm{C}-700^{\circ} \mathrm{C}\right)$ for $80 \mathrm{~min}$ and determined the yields of char, tar, pyrolysis water, and gas Table 6 .

Table 6. The yields of pyrolysis products at different heating temperatures

\begin{tabular}{|c|c|c|c|c|c|}
\hline \multirow{2}{*}{ Coal deposits } & \multirow{2}{*}{ Heating temperatures, ${ }^{\circ} \mathrm{C}$} & \multicolumn{4}{|c|}{ The yields of pyrolysis products, $(\%)$} \\
\hline & & Hard residue & Tar & Pyrolysis water & Gas and loss \\
\hline \multirow{7}{*}{ Tavantolgoi } & 200 & 99.1 & - & 0.6 & 0.3 \\
\hline & 300 & 98.8 & 0.3 & 0.9 & 0.3 \\
\hline & 400 & 97.9 & 0.3 & 1.3 & 0.7 \\
\hline & 500 & 92.3 & 2.5 & 2.8 & 2.3 \\
\hline & 600 & 89.6 & 3.0 & 2.3 & 5.2 \\
\hline & 700 & 84.6 & 3.5 & 4.4 & 7.4 \\
\hline & 800 & 78.9 & 4.0 & 4.6 & 12.4 \\
\hline \multirow{7}{*}{ Nariin sukhait } & 200 & 99.2 & - & 0.2 & 0.5 \\
\hline & 300 & 97.9 & 0.3 & 1.1 & 0.7 \\
\hline & 400 & 95.3 & 0.7 & 2.5 & 1.5 \\
\hline & 500 & 93.0 & 1.1 & 3.5 & 2.5 \\
\hline & 600 & 88.5 & 2.4 & 4.0 & 5.1 \\
\hline & 700 & 83.8 & 3.6 & 6.5 & 6.1 \\
\hline & 800 & 83.3 & 3.5 & 5.1 & 6.1 \\
\hline \multirow{7}{*}{ Baganuur } & 200 & 90.0 & 1.9 & 3.4 & 4.7 \\
\hline & 300 & 90.3 & 0.4 & 4.0 & 5.3 \\
\hline & 400 & 76.6 & 6.6 & 10.4 & 6.4 \\
\hline & 500 & 60.3 & 6.9 & 14.9 & 17.9 \\
\hline & 600 & 56.8 & 7.0 & 14.8 & 21.4 \\
\hline & 700 & 59.5 & 3.5 & 13.1 & 23.9 \\
\hline & 800 & 55.5 & 3.6 & 6.3 & 29.0 \\
\hline
\end{tabular}




\begin{tabular}{|l|l|l|l|l|l|}
\hline \multirow{5}{*}{ Shivee Ovoo } & 200 & 83.0 & 0.0 & 15.8 & 1.2 \\
\cline { 2 - 6 } & 300 & 77.1 & 1.1 & 17.1 & 4.5 \\
\cline { 2 - 6 } & 400 & 75.3 & 3.0 & 17.2 & 4.5 \\
\cline { 2 - 6 } & 500 & 56.5 & 6.3 & 16.8 & 20.4 \\
\cline { 2 - 6 } & 600 & 48.9 & 4.2 & 12.3 & 34.6 \\
\cline { 2 - 6 } & 700 & 48.3 & 3.9 & 11.2 & 36.6 \\
\hline
\end{tabular}

The yields of pyrolysis products at different heating temperatures of pyrolysis Table 6 show that the yield of the hard residue from high-rank coals of Tavan tolgoi $\left(78.9 \%\right.$ at $800^{\circ} \mathrm{C}$ ) and Nariin sukhait $\left(83.3 \%\right.$ at $\left.800^{\circ} \mathrm{C}\right)$ are higher than that of low-rank coals of Baganuur $\left(55.5 \%\right.$ at $\left.800^{\circ} \mathrm{C}\right)$ and Shivee-Ovoo $\left(48.3 \%\right.$ at $\left.700^{\circ} \mathrm{C}\right)$ coal. This indicates that low-rank coals of Baganuur and Shivee-Ovoo coals have given higher yields of tar, pyrolysis water and gas producs during pyrolysis than that of high-rank coals of Tavan tolgoi and Nariin sukhait coal.

The yield of pyrolysis tar chosen as a main product of pyrolysis of four coal samples and according to this the optimum heating temperature of pyrolysis of Tavan tolgoi coal $-4.0 \%$ at $800^{\circ} \mathrm{C}$, Nariin sukhait $-3.6 \%$ at $700^{\circ} \mathrm{C}$, Baganuur $-7.0 \%$ at $600^{\circ} \mathrm{C}$ and Shivee-Ovoo $-6.3 \%$ at $500^{\circ} \mathrm{C}$. This results show that high-rank coals give the increased hard residue and less tar, whereas low-rank coals give more tar and less hard residue after pyrolysis.

The yield of all thermal decomposition products such as liquid and gas products of low-rank coals of Baganuur and Shivee-Ovoo show that there is an intensive thermal decomposition of the coal organic mass with a higher degree of conversion than that of high-rank coals of Tavan tolgoi and Nariin sukhait. As it was mentioned above about the thermal stability of four coal samples that the organic mass of Baganuur and Shivee-Ovo ${ }^{\circ}$ Characterize with lower thermal stability than that of high rank (bituminous) coals of Tavan tolgoi and Nariin sukhait therefore brown coals of Baganuur and Shivee-Ovoo are more suitable for gasification and liquefaction and highrank (bituminous) coals of Tavan tolgoi and Nariin sukhait are more suitable for coking and producing of activated carbons.

The solid product (hard residue or semicoke) after the pyrolysis of four coal samples are one of the main product and for example, the hard residue of Baganuur and Shivee-Ovoo coal can be used as smokeless fuel and activated carbon after briquetting and activation and hard residue of Tavan tolgoi and Nariin sukhait coals can be used as a high-quality coke. For this reason, we have determined the main technical characteristics of the hard residue Table 7.

The proximate analysis results of hard residue after pyrolysis of four coal samples in Table 7 show that the volatile matter content decreased significantly. For example, the content of volatile matter of pyrolysis hard residue of Tavan tolgoi coal decreased 3.1 times, of Nariin sukhait coal 6.3 times, of Shivee-Ovoo coal 2.5 times and of Baganuur coal 5.7 times decreased and increased caloric value in comparison with the initial coal characteristics in Table 1.

Table 7. Main technical characteristics of the pyrolysis hard residue of coals

\begin{tabular}{|c|c|c|c|c|}
\hline \multirow[b]{2}{*}{ Hard residue } & \multicolumn{3}{|c|}{$\begin{array}{l}\text { Main technical characteristics, } \\
\%\end{array}$} & \multirow[b]{2}{*}{$\begin{array}{l}\text { Caloric } \\
\text { value, } \\
\mathbf{Q}^{\text {daf }}, \\
\text { kcal/kg }\end{array}$} \\
\hline & $\begin{array}{l}\text { Moisture, } \\
\text { W }^{\text {a }}\end{array}$ & $\begin{array}{l}\text { Ash, } \\
\mathbf{A}^{\mathrm{d}}\end{array}$ & $\begin{array}{l}\text { Volatile } \\
\text { matters, } \\
\text { V daf }^{\text {dat }}\end{array}$ & \\
\hline Tavantolgoi & 1.1 & 20.1 & 9.5 & \\
\hline Nariinsukhait & 0.6 & 11.5 & 5.8 & 8156.0 \\
\hline Baganuur & 2.8 & 13.9 & 8.3 & 6802.0 \\
\hline Shivee Ovoo & 0.1 & 27.4 & 16.2 & 7337.9 \\
\hline
\end{tabular}

The proximate analysis results of hard residue after pyrolysis of four coal samples in Table 7 show that the volatile matter content decreased significantly. For example, the content of volatile matter of pyrolysis hard residue of Tavan tolgoi coal decreased 3.1 times, of Nariin sukhait coal 6.3 times, of Shivee-Ovoo coal 2.5 times and of Baganuur coal 5.7 times decreased and increased caloric value in comparison with the initial coal characteristics in Table 1. Also, these results show that there was intensive thermal decomposition of coal organic mass of each coal during pyrolysis.

The condensed liquid product usually calls tar which is the main product of pyrolysis of different organic raw materials including coal. Therefore, was decided to characterize the pyrolysis tars of four coal samples. First, all tars were completely removed from the pyrolysis water by centrifuging and drying with thermally treated calcium chloride and filtering. So dewatered tar tested by IR analysis and the FTIR spectra are shown in Figure 6. 


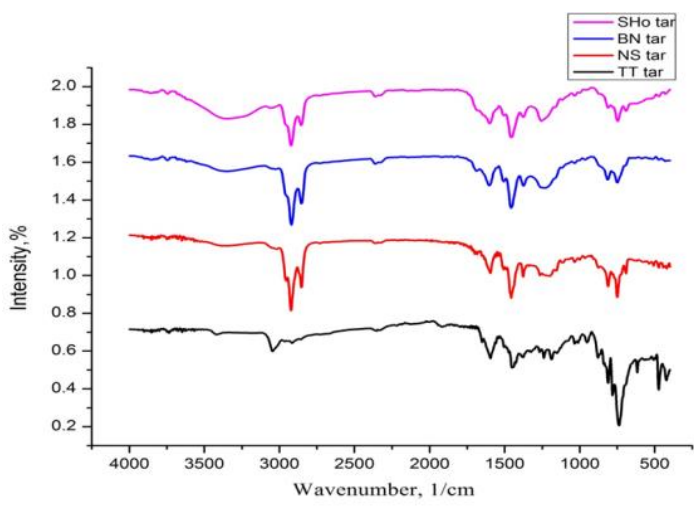

Figure 6. The FTIR spectrum of four pyrolysis tars of Tavan tolgoi (TT), Nariin sukhait (NS), baganuur (BN) and Shivee-Ovoo (ShO) coal

The FTIR spectrum of pyrolysis tars of Tavan tolgoi (TT), Nariin sukhait (NS), Baganuur (BN), and Shivee-Ovoo (ShO) coals are more complicated than FTIR spectra from coal ashes, because they consist of different kinds (classes) of organic compounds with different functional groups and so on. For example, the FTIR spectrum Figure 6 of tar products after pyrolysis were observed the lowest intensity absorption bands for $\mathrm{H}$ of aromatic the $-\mathrm{CH}$ group at $500-800 \mathrm{~cm}^{-1}$ (BN and ShO low-rank coals) and the absorption bands with the highest intensities for $\mathrm{H}$ of aliphatic $-\mathrm{CH}$; $-\mathrm{CH}_{2}$ and $-\mathrm{CH}_{3}$ groups at 2850-2947 $\mathrm{cm}^{-1}$ for four pyrolysis tars. In the case of pyrolysis tars of high rank coals from Tavan tolgoi (TT) and Nariin sukhait (NS) deposits, the peaks for $\mathrm{H}$ of aromatic the $-\mathrm{CH}$ groups at $500-1000 \mathrm{~cm}^{-1}$ are with middle intensities compared with the that of low-rank coal pyrolysis tars from Baganuur (BN) and ShiveeOvoo (ShO) coals.

Also, there are absorption bands with the middle intensity for $\mathrm{O}$ containing groups such as for the $>\mathrm{C}=\mathrm{O}$ groups at $1593 \mathrm{~cm}^{-1}$, for $-\mathrm{O}$ - groups at 1454 $\mathrm{cm}^{-1}$ and the $-\mathrm{OH}$ groups at $3000-3300 \mathrm{~cm}^{-1}$. Therefore, the tar product of coals after pyrolysis consist of mainly the aliphatic, aromatic and aromatic-aliphatic compounds with above mentioned functional groups in their molecules.

The chemical composition of each pyrolysis tar determined by chemical analysis in group organic compounds and the results are given in Table 8 .

The results in Table 8 show that the neutral oils are the main component with the highest content and asphaltenes, free carbons are with middle content.

The contents of organic bases, organic acids, and phenols are the lowest. As mentioned above, organic bases and organic acids were removed from the pyrolysis tar of coals and so purified tar is called a "neutral oil",

The chemical composition of the pyrolysis tar in group organic compounds shows that the tar consists of mainly neutral oils and asphaltenes, and organic bases, organic caids and phenolic compounds are in little amounts. The purified pyrolysis tars were distilled at atmosphere and obtained several fractions with different boiling temperature ranges and the yield of fractions are given in Table 9.

Table 8. The chemical composition of the pyrolysis tar in group organic compounds

\begin{tabular}{|l|l|l|l|l|l|l|}
\hline \multirow{2}{*}{ Coal deposits } & \multicolumn{6}{|l}{ The chemical composition of the tar, \% } \\
\cline { 2 - 7 } & $\begin{array}{l}\text { Free } \\
\text { carbons }\end{array}$ & $\begin{array}{l}\text { Organic } \\
\text { bases }\end{array}$ & $\begin{array}{l}\text { Organic } \\
\text { acids }\end{array}$ & Phenols & Asphalteins & Neutral oils \\
\hline Tavan tolgoi & 13.5 & 0.9 & 0.9 & 2.9 & 16.3 & 65.4 \\
\hline Nariin sukhait & 2.6 & 1.0 & 2.5 & 3.0 & 2.4 & 85.0 \\
\hline Baganuur & 16.1 & 2.5 & 1.7 & 11.9 & 16.1 & 51.7 \\
\hline Shivee-Ovoo & 3.9 & 0.2 & 0.1 & 5.8 & 13.1 & 76.9 \\
\hline
\end{tabular}

Table 9. The yields of fractions of pyrolysis tar of four coals with different boiling temperature ranges, ${ }^{\circ} \mathrm{C}$

\begin{tabular}{|c|l|c|l|}
\hline Coal deposits & $\begin{array}{c}\text { Boiling temperature } \\
\text { range of fraction, }{ }^{\mathbf{}} \mathbf{C}\end{array}$ & The yield of fraction, $\%$ & Discription of fraction \\
\hline \multirow{4}{*}{ Nariin sukhait } & untill 180 & 1.7 & Light fraction (liquid) \\
\cline { 2 - 4 } & $180-250$ & 6.2 & Middle fraction (liquid) \\
\cline { 2 - 4 } & $250-320$ & 12.1 & Middle fraction (liquid) \\
\cline { 2 - 4 } & $320<$ & 6.5 & Heavy fraction (liquid) \\
\cline { 2 - 4 } & Hard residue & 73.5 & Hard \\
\cline { 2 - 4 } & Gas and loss & 0 & Light fraction (liquid) \\
\hline \multirow{3}{*}{ Baganuur } & untill 180 & 0.8 & Middle fraction (liquid) \\
\cline { 2 - 4 } & $180-220$ & 33.1 & Gas fraction (liquid) \\
\cline { 2 - 4 } & $220-250$ & 48.7 & \\
\cline { 2 - 4 } & Hard residue & 17.4 & \\
\hline
\end{tabular}




\begin{tabular}{|c|l|c|l|}
\hline \multirow{4}{*}{ Shivee-Ovoo } & untill 180 & 15.9 & Light fraction (liquid) \\
\cline { 2 - 4 } & $180-320$ & 15.4 & Middle fraction (liquid) \\
\cline { 2 - 4 } & $320<$ & 44.5 & Heavy fraction (liquid) \\
\cline { 2 - 4 } & Gas and loss & 24.1 & Gas \\
\hline \multirow{3}{*}{ Tavan tolgoi IV } & untill 140 & 0.2 & Light fraction (liquid) \\
\cline { 2 - 4 } & $140<$ hard residue & 99.8 & Gas \\
\cline { 2 - 4 } & Gas and loss & 0.04 & \\
\hline
\end{tabular}

Table 9 shows that the main product of the distillation of the pyrolysis tars of four coal samples is the heavy fractions, followed by light and middle fractions with different boiling temperature ranges. Only the pyrolysis tar of Tavan tolgoi coal is a very viscous bitumen-like product at room temperature and therefore it's had $99.7 \%$ hard residue and very little amount of light fraction and gas products and without middle and heavy fractions. After removing the toxic organic compounds such as organic bases, organic acids, and phenols these fractions can be used as gasoline (light fractions), diesel (middle fractions), and oil products (heavy fractions).

\section{CONCLUSION}

In the conclusion, the thermal stability indices from high-rank coal of Tavan tolgoi and Nariin sukhait were much higher than that of lower rank coals of Shivee-Ovoo and Baganuur coals. The yields of pyrolysis products at different heating temperatures showed that the yields of hard residue from Tavan tolgoi and Nariin sukhait are also higher than that of coals from Baganuur and Shivee-Ovoo coal. Importantly, the mineral composition analyses showed that the ashes of high-rank coals from Tavan tolgoi and Nariin sukhait deposits have an acidic character whereas the ashes of low-rank coals of Baganuur and Shivee-Ovoo deposits have the alkaline characteristics.

Moreover, the chemical composition of the pyrolysis tar of Tavan tolgoi, Nariin sukhait, Baganuur, and Shivee-Ovoo coals showed that the pyrolysis tar consists mainly of neutral oils, asphaltenes, organic bases, organic acids, and phenolic compounds. The proximate analysis of the pyrolysis hard residue from four coal samples revealed that the volatile matter contents in these samples were decreased significantly. Besides, our study primarily reports the detailed physic-chemical characteristics of the pyrolysis hard residues from the analyzed four coal samples in comparison to the initial coal samples.

\section{REFERENCES}

[1] Purevsuren B., (2007) Coal is the main source of energy. In Abstracts of papers, Second Korean and Mongolian Energy Conference, Yonsei University, Seoul, 13.

[2] Nikca S., (1991) Flashchain theory for rapid coal devolatilization kinetics. 2. Impact of operating conditions. Energy Fuels, Vol. 5, 665673.

[3] Arenillas A., Rubiera F., Pevida C., Pis J.A., (2001) Comparison of different methods for predicting coal devolatilisation kinetics. Journal of Analytical and Applied Pyrolysis, Vol. 58, 685-701.

[4] Safarova M., Kusy J., Andel L., (2005) Pyrolysis of brown coal under different process conditions. Fuel, Vol. 84, 2280-2285.

[5] Wu D., Liu G., Chen S., Sun R., (2015) An experimental investigation on heating rate effect in the thermal behavior of perhydrous bituminous coal during pyrolysis. Journal of Thermal Analysis and Calorimetry, Vol. 119(3), 2195-2203.

[6] Purevsuren B., Davaajav Ya., Erdenechimeg R., (2010) Investigation on coals from some Mongolian deposits. Toonotprint publisher, Ulaanbaatar, 14-22 (in Mongolian).

[7] Avid B., Purevsuren B., Temuujin J., (2016) Bituminous Coals of Mongolia: ${ }^{\circ}$ Ccurrence and Characteristics. In: Advances in Energy Research Morena J.Acosta (ed.), Vol. 22, Chapter 7, Nova Publishers, New York, 159178.

[8] Avid B., Sato Y., Maruyama K., Yamada Y., Purevsuren B., (2004) Effective utilization of Mongolian coal by upgrading in a solvent. Fuel Processing Technology, Vol. 85, 933-945.

[9] Purevsuren B., Davaajav Ya., (2006) Investigation on pyrolysis of some organic raw materials, Toonotprint publisher, Ulaanbaatar, 11-28 (in Mongolian).

[10] Purevsuren B., (2003) Selected works on synthesis of polymers and pyrolysis of organic 
raw materials and characterization of obtained products. Toonotprint publisher, Ulaanbaatar, 81-87.

[11] Ariunaa A., Li B.Q., Li W., Purevsuren B., Sh.Munkhjargal., et al. (2007) Coal pyrolysis under synthesis gas, hydrogen and nitrogen. Journal of Fuel Chemistry and Technology., Vol. 35(1), 1-4.

[12] Purevsuren B., Davaajav Ya., (2001) Thermal analysis of casein. Journal of Thermal Analysis and Calorimetry, Vol. 65, 147-152.

[16] Munkhjargal Sh., Purevsuren B., (1998) Products of pyrolysis of wood wastes. Reports of the Institute of Chemistry, MAS, 25-28.

[17] Otgonchuluun D., Purevsuren B., Ariunaa A., (2014) Investigation on pyrolysis and characterization of solid and liquid products after pyrolysis of wood waste. Reports of the Mongolian University of Science and Technology, Vol. 2, 68-171.

[18] Purevsuren B., Otgonchuluun D., Ariunaa A., (2015) Pyrolysis of wood waste and characterization of obtained products. Reports of the Mongolian Chemical $\mathrm{S}^{\circ}$ Ciety, Vol. 10, 21-30.

[19] Purevsuren B., Avid B., Gerelmaa T., Davaajav Ya., Morgan T.J., et al., (2004) The characterization of tar from pyrolysis of animal bones. Journal of Fuel Chemistry and Technology, Vol. 83, 799-805.

[20] Batbileg S., Purevsuren B., Davaajav Ya., Narangerel J., (2015) Investigation on chemical composition of tar from cedar shell. Scientific Reports of Institute of Chemistry and Chemical Technology, Vol 2, 92-97. (in Mongolian)
[13] Avid B., Purevsuren B., et al., (2002) Pyrolysis and TG analysis of the Shivee Ovoo coal Mongolia. Journal of Thermal Analysis and Calorimetry, Vol. 68, 877-885.

[14] Avid B., Purevsuren B., (2001) Chemical composition of organic matter of the Mongolian Khoot oil shale. Oil shale, Vol. 18(1), 18-23.

[15] Avid B., Born M., Purevsuren B., Undrakh N., Tuvshinjargal A., (2003) Thermal behavior of the Khoot oil shale in the different conditions.

[21] Purevsuren B., Davaajav Ya., Karaca F., Morgan T.J., George A., et al., (2009) Pyrolysis

[22] Purevsuren B., Davaajav Ya., (2001) Investigation on pyrolysis of casein. Journal of Thermal Analysis and Calorimetry, Vol. 66, 743-748.

[23] Purevsuren B., Avid B., Tesche B., Davaajav Ya., (2003) $\mathrm{A} \mathrm{bi}^{\circ}$ Char from casein and its properties. Journal of Material science, Vol. $38(11), 2347-2351$.

[24] Purevsuren B., Avid B., Davaajav Ya., Herod A., Kandiyoti R., et al., (2004) Estimation of the molecular mass range of the tar from pyrolysis of casein by gas chromatography-mass spectrometry, probe mass spectrometry and size-exclusion chromatography with 1-methyl2-pyrrolidinone as eluent. European Journal of Mass Spectrometry, Vol. 10, 101-108.

[25] Purevsuren B., Davaajav Ya., Genadiev V., Kotsev H., Glavchev I., (2013) Investigation of the liquid tar product from pyrolysis of yak-milk casein and its application in curring of epoxy resin. Bulgarian Chemical Communications, Vol. 45(2) 157-160. 